\title{
ANALISIS FAKTOR RISIKO KEKURANGAN ENERGI KRONIS IBU HAMIL DI KOTA PAREPARE
}

\section{Analysis of Risk Factors for Chronic Energy Deficiency in Pregnant Women in the City of Parepare}

\author{
Nurkhaira Mazita $\mathbf{J}^{1}$, Andi Nuddin ${ }^{2}$, Henni Kumaladewi Hengky \\ ${ }^{1}$ Mahasiswa Konsentrasi Epidemiologi Fakultas Ilmu Kesehatan Universitas Muhammadiyah \\ Parepare \\ ${ }^{2}$ Dosen Program Studi Kesehatan Masyarakat Universitas Muhammadiyah Parepare \\ ${ }^{3}$ Dosen Program Studi Kesehatan Masyarakat Universitas Muhammadiyah Parepare \\ (Ichahera77@gmail.com)
}

\begin{abstract}
ABSTRAK
Kekurangan Energi Kronis (KEK) adalah salah satu keadaan malnutrisi pada ibu hamil, yang dapat di ukur melalui pengukuran Lingkar Lengan Atas (LILA) menggunakan pita LILA). Secara umum Pravalensi KEK di Sulawesi Selatan hanya 12,5\% termasuk Kota Parepare yang pravelansinya $(9,75 \%)$. Tujuan Penelitian ini untuk menunjukkan apakah faktor usia ibu, jarak kehamilan, asupan zat gizi dan pantang makan mempengaruhi Risiko KEK ibu hamil di Kota Parepare.Metode yang digunakan dalam penelitian ini adalah metode analitik dengan pendekatan Cross Sectional Study. Peneliti mengidentifikasi melalui observasional dengan menggunakan kuesioner pada sampel, dimana sampel dalam penelitian ini sebanyak 63 orang ibu hamil di Kota Parepare. Data dianalisis secara univariat dan bivariat menggunakan uji statistik Chi Square melalui SPSS Versi 24 Hasil penelitian menunjukkan bahwa ada pengaruh Usia Ibu 0,030, ada pengaruh Jarak Kehamilan 0,488, tidak ada pengaruh Asupan Zat Gizi 0,341 dan ada pengaruh Pantang Makan 0,000 terhadap Risiko KEK ibu hamil di Kota Parepare. Disarankan sebaiknya pada wanita yang ingin menikah merencanakan terlebih dahulu jika ingin menikah muda dikarenakan umur yang baik untuk menikah ialah 20-35 tahun dikarenakan pada usia itu kondisi yang baik dalam kehamilan, sebaiknya ibu hamil lebih banyak mengkonsumsi makanan yang sangat diperlukan oleh janin dan lebih banyak memperluas pengetahuan tentang kehamilan dan makanan yang dikonsumsinya dan bagi pasangan usia subur (PUS) yang menginginkan kehamilan sebaiknya dipersiapkan secara menyeluruh terutama kebutuhan akan makanan yang dibutuhkan ibu sebelum dan selama hamil sehingga tidak terjadi defisiensi Gizi terutama kebutuhan akan Energi.
\end{abstract}

Kata Kunci : Kekurangan Enegi Kronis (KEK), usia ibu, jarak kehamilan, asupan zat gizi dan pantang makan

ABSTRACT

Chronic Energy Deficiency (SEZ) is one of the conditions of malnutrition in pregnant women, which can be measured through the measurement of the Upper Arm Circumference (LILA) using the LILA tape. ) In general, in South Sulawesi the prevalence of SEZs is only 12.5\%, including the pravelans' Parepare City (9.75\%). The purpose of this study is to show whether maternal age, pregnancy distance, nutrient intake and abstinence affect the risk of SEZ in pregnant women in the city of Parepare. The method used in this study is an analytical method with a Cross Sectional Study 
approach. The researcher identified through observational using a questionnaire on the sample, where the sample in this study were 63 pregnant women in the city of Parepare. Data were analyzed by univariate and bivariate using Chi Square statistic test through SPSS Version 24. The results showed that there was an influence of Maternal Age 0.030, there was an effect of Pregnancy Distance 0.488, no effect of Nutrition Intake 0.341 and there was an effect of Abstinence 0.000 on Risk of SEZ in pregnant women Parepare City. It is recommended that women who want to get married plan first if you want to get married young because the good age for marriage is 20-35 years because at that age a good condition in pregnancy, you should consume more food that is needed by the fetus and more expanding knowledge about pregnancy and the food consumed and for couples of childbearing age (PUS) who want pregnancy should be prepared thoroughly, especially the need for food needed by the mother before and during pregnancy so that there is no nutritional deficiency, especially the need for energy

Keywords: Chronic Energy Deficiency (SEZ), maternal age, distance in pregnancy, nutrition intake and never eat 


\section{PENDAHULUAN}

Angka Kematian Ibu (AKI) di Indonesia sejak tahun 1991 hingga 2007 mengalami penurunan dari 390 menjadi 228 per 100.000 kelahiran hidup. Namun, Survei Demografi Kesehatan Indonesia (SDKI) kembali mencatat kenaikan AKI yang signifikan pada tahun 2012, yakni dari 228 menjadi 359 kematian ibu per 100.000 kelahiran hidup. Di samping itu angka kematian bayi (AKB) mengalami penurunan sejak tahun 1991 dari 68 per 1.000 kelahiran hidup menjadi 34 per 1.000 kelahiran hidup pada tahun 2007, sedangkan tahun 2012 mencapai 32 per 1.000 kelahiran hidup. Baik AKI maupun AKB tidak berhasil mencapai target Millenium Depelopment Goals (MDGs) pada tahun 2015, yaitu AKI 102 per 100.000 kelahiran hidup dan AKB 23 per 1.000 kelahiran hidup. ${ }^{1}$

Salah satu penyebab tingginya AKI dan AKB adalah meningkatnya risiko kurang energi kronis (KEK). KEK merupakan suatu keadaan ibu menderita kekurangan makanan yang berlangsung menahun (kronis) sehingga menimbulkan gangguan kesehatan pada ibu hamil. $^{2}$

Kekurangan energi kronis pada Ibu Hamil sedang menjadi fokus pemerintah dan tenaga kehehatan sekarang ini. Hal ini dikarenakan seorang Ibu Hamil memiliki risiko tinggi untuk terkena dan melahirkan anak yang akan menderita KEK dikemudian hari. Selain itu, kekurangan gizi menimbulkan masalah kesehatan (morbiditas, mortalitas, dan disabilitas), juga menurunkan kualitas Sumber Daya Manusia (SDM) suatu bangsa. Dalam skala yang lebih luas, kekurangan gizi dapat menjadi ancaman bagi ketahanan dan kelangsungan hidup suatu bangsa. ${ }^{3}$

Hasil Riset Kesehatan Dasar (Riskesdas) 2013 didapatkan angka prevalensi risiko KEK di Indonesia adalah 31,3\% pada wanita hamil dan $20,8 \%$ pada WUS. Kabupaten Kota yang mengalami KEK dengan prevalensi < $10 \%$ yaitu Soppeng (9,4\%), Pinrang (8\%), Enrekang (8,8\%), Luwuk utara (7,5\%), Makassar (7,7\%) dan Palopo (9.1\%), sedangkan kabupaten yang memiliki pravalensi KEK tertinggi adalah Tanah Toraja dengan $(33,7 \%)$ (Riskesdas, 2007). Secara umum di Sulawesi Selatan Pravalensi KEK hanya 12,5\% termasuk Kota Parepare yang pravelansinya $(9,75 \%)$. Hal ini menunjukkan bahwa kawasan Timur Indonesia masih memerlukan perhatian yang lebih besar dalam upaya peningkatan gizi masyarakat. ${ }^{4}$

Faktor-faktor yang memengaruhi KEK pada Ibu Hamil terbagi menjadi dua, yaitu faktor internal dan eksternal. Internal (individu/keluarga) yaitu genetik, obstetrik, seks. Sedangkan eksternal adalah gizi, obatobatan, lingkungan, dan penyakit. ${ }^{5}$ 
Penilitian mengenai faktor - faktor yang berhubungan dengan kekurangan energi kronis (KEK) pada ibu hamil di Kota Parepare pada tahun pada tahun 2013 mendapatkan hasil bahwa 60,0 \% ibu hamil dengan KEK menikah pada usia $<20$ tahun. Tidak terdapat hubungan yang bermakna antara usia menikah dengan kejadian KEK. Namun, hampir semua ibu hamil dengan KEK menikah pada usia $<20$ tahun dipengaruhi oleh Usia Kehamilan Pertama. ${ }^{6}$

Disamping itu jarak persalinan yang baik dan tidak mempunyai risiko yaitu bila jarak satu kelahiran dengan kehamilan yang lainnya antara 3 sampai 4 tahun. Apabila makanannya tidak mencukupi selama kehamilan makan ibu hamil tersebut dalam masalah besar. Hal ini karena pada masa hamil dan menyusui membutuhkan gizi yang besar. Ibu dengan jumlah kehamilan lebih dari 3 kali juga akan mengalami kesulitan untik pertambahan berat badan yang dibutuhkan.

Keadaan gizi, kesehatan dan emosional ibu hamil serta pengalaman ibu selama kehamilan akan menentukan kualitas bayi yang dilahirkan dan perkembangan selanjutnya. Jika status kesehatan ibu sebelum dan selama kehamilan dalam keadaan baik maka besar peluang janin yang dikandungnya akan bertumbuh dengan baik dan keselamatan ibu selama proses melahirkan juga menjadi terjamin. Salah satu permasalahan dalam kehamilan yang berkaitan dengan gizi adalah energi kronis (KEK).
Disamping itu dalam penelitiannya mengenai hubungan antara pola konsumsi, penyakit infeksi dan pantang makanan terhadap risiko kurang energi kronis (KEK) pada ibu hamil di Kota Parepare memperoleh hasil bahwa ibu hamil memiliki pantang makanan selama kehamilan yaitu 30,6\%. Dari hasil analisis bivariat diperoleh hubungan yang bermakna antara risiko KEK dengan budaya pantang makanan

Sampai saat ini masih banyak ibu hamil yang mengalami masalah gizi khususnya gizi kurang dalam asupan gizi. Lingkar lengan atas (LILA) adalah jenis pemeriksaan antropometri yang digunakan untuk mengukur risiko KEK pada wanita usia subur yang meliputi remaja, ibu hamil, ibu menyusui, dan pasangan usia subur (PUS). Gizi janin bergantung sepenuhnya kepada ibu dan kecukupan gizi ibu sangat mempengaruhi janin yang dikandungnya, seperti wanita usia subur dengan LILA > 23,5 cm asupan energi protein yang jika tidak mencukupi pada ibu hamil dapat menyebabkan kurang energi kronis. Wanita hamil berisiko KEK jika memiliki LILA $<23,3 \mathrm{~cm}^{4}{ }^{4}$

Ibu hamil yang mengalami risiko KEK akan menimbulkan beberapa masalah, baik pada ibu maupun janin. KEK pada ibu hamil dapat menyebabkan risiko dan komplikasi. Faktor - faktor yang berhubungan dengan KEK pada ibu hamil diantaranya adalah keadaan sosial ekonomi yang mengakibatkan rendahnya jarak kelahiran 
yang terlalu dekat menyebabkan buruknya gizi pada ibu hamil, dan pekerjaan yang biasanya mempengaruhi paritas, status gizi lebih rendah apabila diimbangi dengan asupan makanan dalam jumlah yang cukup serta mengimbangi dalam pengeluaran pangan dan faktor perilaku yang mendukung tumbuh kembang janin dan kesehatan ibu. $^{7}$

Berdasarkan hal diatas, maka peneliti berkeinginan untuk mengetahui "Analisis Faktor Risiko Kekurangan Energi Kronis Ibu Hamil di Kota Parepare"

\section{BAHAN DAN METODE}

Jenis penelitian yang digunakan dalam penelitian ini adalah metode analitik dengan rancangan penelitian cross sectional study, yaitu suatu penelitian dimana tiap objek penelitian hanya di observasi sekali saja dengan menggunakan kuesioner, kemudian dianalisis apakah usia kehamilan, jarak kehamilan, paritas, pengeluaran rumah tangga, asupan zat gizi, dan aktifitas fisik mempengaruhi faktor risiko KEK ibu hamil di Kota Parepare.

Penelitian ini dilaksanakan di kota parepare pada bulan april sampai dengan juni. Populasi terjangkau untuk penelitian ini adalah semua Ibu Hamil yang memeriksakan diri di beberapa puskesmas yang ada di Kota Parepare sebanyak 165 orang dengan sampel sebesar 63 orang dan memakai analisis univariat dan bivariat (c-square).

\section{HASIL}

Hasil penelitian pada Tabel 1 menunjukkan bahwa dari mayoritas ukuran LILA ibu hamil tertinggi terdapat pada kelompok berisiko yakni sebanyak 39 orang $(61,9 \%)$ dan ukuran LILA ibu hamil yang terendah terdapat terdapat pada kelompok tidak berisiko yakni sebanyak 24 orang $(38,1 \%)$. Menurut usia ibu hamil, rata - rata nilai teratas terdapat pada kelompok tinggi yakni sebanyak 27 orang (42,9\%), usia ibu hamil yang terbawah terdapat pada kelompok rendah yakni sebanyak 14 orang $(22,2 \%)$ dan kelompok sedang yakni sebanyak 22 orang $(34,9 \%)$. Menurut jarak kehamilan nilai teratas terdapat pada kelompok tinggi yakni sebanyak 36 orang $(57,1 \%)$ dan tnilai terbawah yakni kelompok rendah sebanyak 10 orang $(15,9 \%)$. Menurut asupan gizi pada kelompok kurang yakni sebanyak 39 orang $(57,1 \%)$ dan jumlah terendah pada kelompok cukup yakni sebanyak 27 orang (42,9\%).Terakhir jumlah ibu hamil yang memiliki pantang makan yakni sebanyak 37 orang $(58,7 \%)$ dan jumlah ibu hamil yang tidak memiliki pantang makan yakni sebanyak 26 orang $(41,3 \%$

Hasil penelitian pada Tabel 2 menggambarkan pengaruh usia ibu terhadap risiko KEK ibu hamil di Kota Parepare. Berdasarkan tabel terlihat bahwa terdapat 39 ibu hamil yang menderita KEK diantaranya 21 orang $(77,8 \%)$ memiliki usia $<20,9$ orang $(40,9 \%)$ yang memiliki usia 20 - 35 tahun dan 9 orang $(64,3 \%)$ yang memiliki usia $\geq 35$ 
tahun. Sedangkan dari 24 ibu hamil yang tidak menderita diantaranya 6 orang $(22,2 \%)$ yang memiliki usia $<20,13$ orang $(59,1 \%)$ yang memiliki usia 20 - 35 tahun dan 5 orang $(35,7 \%)$ yang memiliki usian $\geq 35$ tahun. Hasil analisis dengan menggunakan analisis $C$ Square diperoleh ada pengaruh usia ibu dengan KEK di Kota Parepare. $(\mathrm{p}=0,030)$

Hasil penelitian pada Tabel 3 menggambarkan pengaruh jarak kehamilan terhadap risiko KEK ibu hamil di Kota Parepare. Berdasarkan tabel terlihat bahwa terdapat 39 ibu hamil yang menderita KEK diantaranya 20 orang $(55,6 \%)$ memiliki jarak kehamilan $<2$ tahun, 12 orang $(70,6 \%)$ yang memiliki jarak kehamilan $2-3$ tahun dan 7 orang $(70,0 \%) \geq 3$ tahun. Sedangkan dari 24 ibu hamil yang tidak menderita diantaranya, 16 orang $(44,4 \%)$ yang memiliki jarak kehamilan $<2$ tahun, 5 orang $(29,4 \%)$ yang memiliki jarak kehamilan $2-3$ tahun, dan 3 orang $(30,0 \%)$ yang memiliki jarak kehamilan $\geq 3$ tahun. Hasil analisis dengan menggunakan analisis C-Square diperoleh tidak ada pengaruh jarak kehamilan dengan KEK di Kota Parepare. $(p=0,488)$

Hasil penelitian pada Tabel 4 menggambarkan pengaruh asupan zat gizi terhadap risiko KEK ibu hamil di Kota Parepare. Berdasarkan tabel terlihat bahwa terdapat 39 ibu hamil yang menderita KEK diantaranya 18 orang $(66,7 \%)$ ibu hamil yang memiliki asupan gizi $\geq 80$ AKG dan 21 orang $(58,8 \%)$ ibu hamil yang memiliki $<80$ AKG.
Sedangkan dari 24 ibu hamil yang tidak menderita KEK, diantaranya 9 orang $(33,3 \%)$ ibu hamil yang memiliki $\geq 80$ AKG dan 15 orang $(41,7 \%)$ ibu hamil yang memiliki $<80$ AKG. Hasil analisis C-Square diperoleh tidak ada pengaruh asupan zat gizi dengan KEK di Kota Parepare. $(p=0,341)$

Hasil penelitian pada Tabel 5 menggambarkan pengaruh pantang makan terhadap risiko KEK ibu hamil di Kota Parepare. Berdasarkan tabel terlihat bahwa terdapat 39 ibu hamil yang menderita KEK diantanya. 31 orang $(83,8 \%)$ ibu hamil memiliki pantang makan dan 8 orang $(30,8 \%)$ ibu hamil yang tidak memiliki pantang makan. Sedangkan daru 24 responden yang tidak menderita KEK diantanya, 6 orang $(16,2 \%)$ ibu hamil yang memiliki pantang makan, dan 18 orang $(69,3 \%)$ ibu hamil yang tidak memiliki pantang makan.Hasil analisis C-Square diperoleh ada pengaruh pantang makan dengan KEK di Kota Parepare. ( $\mathrm{p}=$ $0,00)$

\section{PEMBAHASAN}

Berdasarkan hasil penelitian didapatkan hasil $p$-value $0,488(\mathrm{p}>0,05)$ atau dapat dikatakan tidak ada hubungan yang signifikan antara jarak kelahiran dengan keadaan KEK ibu hamil di Kota Parepare. Dari hasil analisis maka ibu hamil yang jarak kehamilannya kurang dari dua tahun mempunyai risiko untuk terkena KEK dibandingkan dengan ibu hamil yang jarak kelahirannya lebih dari 2 tahun. 
Jarak melahirkan yang terlalu dekat < 2 tahun akan menyebabkan kualitas janin atau anak yang rendah dan juga akan merugikan kesehatan ibu. Jarak melahirkan yang terlalu dekat akan menyebabkan ibu tidak memperoleh kesempatan untuk memperbaiki tubuhnya sendiri dimana ibu memerlukan energi yang cukup untuk memulihkan keadaan setelah melahirkan anaknya. Ibu juga masih dalam masa menyusui dan harus memenuhi kebutuhan gizi selama menyusui, dimana saat menyusui ibu membutuhkan tambahan kalori setiap hari untuk memenuhi gizinya dan produksi ASI, dengan hamil kembali maka akan menimbulkan masalah gizi ibu dan janin atau bayi berikut yang dikandung.

Berdasarkan hasil penelitian didapatkan hasil $p$-value $0,341(\mathrm{p}<0,05)$ atau dapat dikatakan tidak ada hubungan yang signifikan antara jumlah konsumsi Energi dan Protein dengan KEK pada ibu hamil di Kota Parepare. Dari hasil analisis maka ibu hamil yang jumlah konsumsi energinya diatas 8099\% AKG tidak mempunyai risiko untuk terkena KEK dibandingkan ibu hmail yang jumlah konsumsinya 70-80\% AKG.

Dari hal tersebut dapat disimpulkan bahwa konsumsi energi ibu hamil hubungannya dengan tingkat pengetahuan ibu berkaitan erat dengan sikap ibu. Artinya, semakin tinggi pengetahuan ibu, maka akan semakin memudahkan ibu dalam mendapatkan informasi mengenai kesehatan terutama yang berkaitan dengan masalah kehamilan.
Selanjutnya berdasarkan pengetahuan yang didapatkan, ibu dapat menentukan sikap dan perilaku dalam pemilihan asupan zat gizi yang akan dikonsumsinya pada saat mengalami kehamilan dengan memanfaatkan alat elektronik untuk memenuhi informasi bagaimana meningkatkan asupan enrgi selama masa kehamilan agar kesehatan ibu dan janin terjaga dengan baik selama masa kehamilan.

Berdasarkan hal tersebut disimpulkan bahwa asupan gizi pada ibu hamil tidak mempengaruhi Risiko KEK ibu hamil di Kota Parepare dikarenakan tingkat pengetahuan berkaitan erat dalam sikap ibu dalam memilih makanan yang baik.

Berdasarkan hasil penelitian didapatkan hasil $p$-value 0,000 ( $\mathrm{p}<0,05)$ atau dapat dikatakan ada hubungan antara pantangan makanan dengan keadaan KEK pada ibu hamil di Kota Parepare. Dari hasil ananlisis maka yang berpantangan terhadap makanan mempunyai risiko relatif sama untuk terkena KEK dibandingkan dengan ibu hamil yang tidak berpantangan tehadap makanan.

Hal ini terjadi karena ibu hamil berpantangan makanan - makanan yang merugikan ataupun membahayakan kesehatan serta mengganggu kebutuhan akan gizi karena zat gizi yang terkandung di dalam makanan tersebut dapat diperoleh pada makanan yang dipanangnya. Dengan adanya hal tersebut maka juga mempengaruhi kolerasi antara 
pantangan makanan dengan KEK pada ibu hamil di Kota Parepare.

Hal tersebut dikarenakan ibu hamil kurnag memiliki pengetahuan dalam hal memilih makanan yang baik untuk dikonsumsi dan kebanyakan ibu hamil masih terpangaruh dengan adanya budaya pantang makan terhadap makanan yang sebenarnya diperlukan oleh janin. Sehingga banyak dari ibu hamil memiliki pantang makan yang janin butuhkan pada saat kelahiran nantinya, beranggapan makanan yang dikonsumsi dapat mempengaruhi janin pada saat melahirkan sehingga para ibu beranggapan bahwa terlalu banyak mengkonsumsi gizi yang berlebih akan berpengaruh besar kecilnya bayi yang akan dilahirkan.

\section{KESIMPULAN DAN SARAN}

Berdasarkan hasil penelitian dari analisis faktor risiko kekurangan energi kronis ibu hamil di Kota Parepare, maka diperoleh kesimpulan bahwa ada pengaruh usia ibu pantang makan dengan risiko KEK dan tidak ada pengaruh jarak kehamilan dan asupan zat gizi dengan risiko KEK . Disarankan sebaiknya pada wanita yang ingin menikah merencanakan terlebih dahulu jika ingin menikah muda dikarenakan umur yang baik untuk menikah ialah 20-35 tahun dikarenakan pada usia itu kondisi yang baik dalam kehamilan, Sebaiknya ibu hamil lebih banyak mengkonsumsi makanan yang sangat diperlukan oleh janin dan lebih banyak memperluas pengetahuan tentang kehamilan dan makanan yang dikonsumsinya dan bagi pasangan usia subur (PUS) yang menginginkan kehamilan sebaiknya dipersiapkan secara menyeluruh terutama kebutuhan akan makanan yang dibutuhkan ibu sebelum dan selama hamil sehingga tidak terjadi defisiensi Gizi terutama kebutuhan akan Energi.

\section{DAFTAR PUSTAKA}

1. Kementerian Kesehatan Republik Indonesia. Profil Kesehatan Indonesia 2014. Jakarta: Kementerian Kesehatan Republik Indonesia; 2015

2. Departemen Kesehatan RI. Keputusan Menteri Kesehatan Nomor 1995/MENKES/SK/XII/2010. Jakarta: Kementerian Kesehatan Republik Indonesia; 2015.

3. Musni M, dkk. Faktor - Fakto Yang Berhubungan Dengan Kekurangan Energi Kronis (KEK) Pada Ibu Hamil. Jurnal AKBID Bataritoja; 2017.

4. Dinas Kesehatan. Profil Dinas Kesehatan Provinsi Sulawesi Selatan. Makassar: Dinas Kesehatan Provinsi Sulawesi Selatan; 2017.

5. Schaible dan Kauffman. 2007. Dalam: Hidayati F. 2011. Hubungan Antara Pola Konsumsi, Penyakit Infeksi dan Pantang Makanan Terhadap Risiko Kurang Energi Kronis (KEK) Pada Ibu Hamil di Puskesmas Ciputat Kota Tangerang 
Selatan tahun 2011 [skripsi]. Jakarta:

Universitas Islam Negeri Syarif

Hidayatullah Jakarta; 2011.

6. Mahirawati VK. Faktor-Faktor Yang Berhubungan Dengan Kekurangan Energi

Kronis (KEK) Pada Ibu Hamil Di

Kecamatan Kamoning dan Tambelengan
Kabupaten Sampang Provinsi Jawa Timur.

Buletin Penelitian Sistem Kesehatan; 2014:17(2):193-202

7. Aryani. DE. Validita Lingkar Lengan Atas Mendeteksi Risiko Kekurangan Energi Kronis Pada Wanita Indonesia. Jurnal Kesehatan Masyarakat National; 2012. 


\section{LAMPIRAN}

Tabel 1. Distribusi Variabel Penelitian terhadap Risiko KEK Ibu hamil di Kota Parepare

\begin{tabular}{|c|c|c|}
\hline Variabel & Frekuensi & Persen $(\%)$ \\
\hline \multicolumn{3}{|l|}{ LILA } \\
\hline Berisiko $(<23,5 \mathrm{~cm})$ & 39 & 61,9 \\
\hline Tidak Berisiko $(>23,5 \mathrm{~cm})$ & 24 & 38,1 \\
\hline Total & 63 & 100.0 \\
\hline \multicolumn{3}{|l|}{ Usia Ibu } \\
\hline Tinggi ( $<20$ tahun) & 27 & 42,9 \\
\hline Sedang ( $\geq 35$ tahun) & 22 & 34,9 \\
\hline Rendah (20 - 35 tahun) & 14 & 22,2 \\
\hline Total & 63 & 100.0 \\
\hline \multicolumn{3}{|l|}{ Jarak Kehamilan } \\
\hline Tinggi $(<2$ tahun $)$ & 36 & 57,1 \\
\hline Sedang (2-3 tahun) & 17 & 27,0 \\
\hline Rendah ( $\geq 3$ tahun $)$ & 10 & 15,0 \\
\hline Total & 63 & 100.0 \\
\hline \multicolumn{3}{|l|}{ Asupan Zat Gizi } \\
\hline Cukup ( $\geq 80 \%$ AKG) & 14 & 22,2 \\
\hline Kurang $(<80 \%$ AKG $)$ & 49 & 77,8 \\
\hline Total & 63 & 100.0 \\
\hline \multicolumn{3}{|l|}{ Pantang Makan } \\
\hline $\mathrm{Ya}$ & 37 & 58,7 \\
\hline Tidak & 26 & 41,3 \\
\hline Total & 63 & 100.0 \\
\hline
\end{tabular}

Tabel 2. Hubungan antara Usia Ibu terhadap faktor risiko KEK ibu hamil di Kota Parepare

\begin{tabular}{|c|c|c|c|c|c|c|c|}
\hline \multirow{3}{*}{ Usia Ibu } & \multicolumn{7}{|c|}{ KEK } \\
\hline & \multicolumn{2}{|c|}{ Menderita } & \multicolumn{2}{|c|}{ Tidak Menderita } & \multicolumn{2}{|c|}{ Total } & \multirow{2}{*}{$\mathrm{P}$} \\
\hline & $\mathrm{n}$ & $\%$ & $\mathrm{n}$ & $\%$ & $\mathrm{~N}$ & $\%$ & \\
\hline Tinggi & 21 & 77,8 & 6 & 22.2 & 27 & 100,0 & \multirow{4}{*}{0,030} \\
\hline Sedang & 9 & 40,9 & 13 & 59,1 & 22 & 100,0 & \\
\hline Rendah & 9 & 64,3 & 5 & 35,7 & 14 & 100,0 & \\
\hline Total & 39 & 61,9 & 24 & 38,1 & 63 & 100,0 & \\
\hline
\end{tabular}


Tabel 3. Hubungan antara Jarak Kehamilan dengan faktor risiko KEK ibu hamil di Kota Parepare

\begin{tabular}{|c|c|c|c|c|c|c|c|}
\hline \multirow{3}{*}{ Jarak Kehamilan } & \multicolumn{7}{|c|}{ KEK } \\
\hline & \multicolumn{2}{|c|}{ Menderita } & \multicolumn{2}{|c|}{ 「idak Menderita } & \multicolumn{2}{|c|}{ Total } & \multirow[b]{2}{*}{$\mathrm{P}$} \\
\hline & $\mathrm{n}$ & $\%$ & $\mathrm{n}$ & $\%$ & $\mathrm{~N}$ & $\%$ & \\
\hline Tinggi & 20 & 55,6 & 16 & 44,4 & 36 & 100,0 & \multirow{4}{*}{0,488} \\
\hline Sedang & 12 & 70,6 & 5 & 29,4 & 17 & 100,0 & \\
\hline Rendah & 7 & 70,0 & 3 & 30,0 & 10 & 100,0 & \\
\hline Total & 39 & 72,0 & 24 & 38,1 & 63 & 100,0 & \\
\hline
\end{tabular}

Tabel 4. Hubungan antara Asupan zat gizi dengan Faktor risiko KEK ibu hamil di Kota Parepare

\begin{tabular}{|c|c|c|c|c|c|c|c|}
\hline \multirow{3}{*}{ Asupan zat gizi } & \multicolumn{7}{|c|}{ KEK } \\
\hline & \multicolumn{2}{|c|}{ Menderita } & \multicolumn{2}{|c|}{ Tidak Menderita } & \multicolumn{2}{|c|}{ Total } & \multirow{2}{*}{$\mathrm{P}$} \\
\hline & $\mathrm{n}$ & $\%$ & $\mathrm{~N}$ & $\%$ & $\mathrm{~N}$ & $\%$ & \\
\hline Cukup & 18 & 66,7 & 9 & 33,3 & 27 & 100,0 & \multirow{3}{*}{0,341} \\
\hline Kurang & 21 & 58,8 & 15 & 41,7 & 36 & 100,0 & \\
\hline Total & 39 & 61,9 & 24 & 38,1 & 63 & 100,0 & \\
\hline
\end{tabular}

Tabel 5. Hubungan antara Pantang makan dengan Faktor risiko KEK di Kota Parepare

\begin{tabular}{ccccccccc}
\hline & \multicolumn{7}{c}{ KEK } & \multirow{2}{*}{ T } \\
\cline { 2 - 7 } Pantang Makan & \multicolumn{2}{c}{ Menderita } & \multicolumn{7}{c}{ Tidak Menderita } & \multicolumn{2}{c}{ Total } \\
\cline { 2 - 7 } & $\mathrm{n}$ & $\%$ & $\mathrm{n}$ & $\%$ & $\mathrm{~N}$ & $\%$ & \\
\hline Ya & 31 & 83,8 & 6 & 16,2 & 37 & 100,0 & \\
Tidak & 8 & 30,8 & 18 & 69,3 & 26 & 100,0 & 0,000 \\
\hline Total & 39 & 61,9 & 24 & 38,1 & 63 & 100,0 & \\
\hline
\end{tabular}

